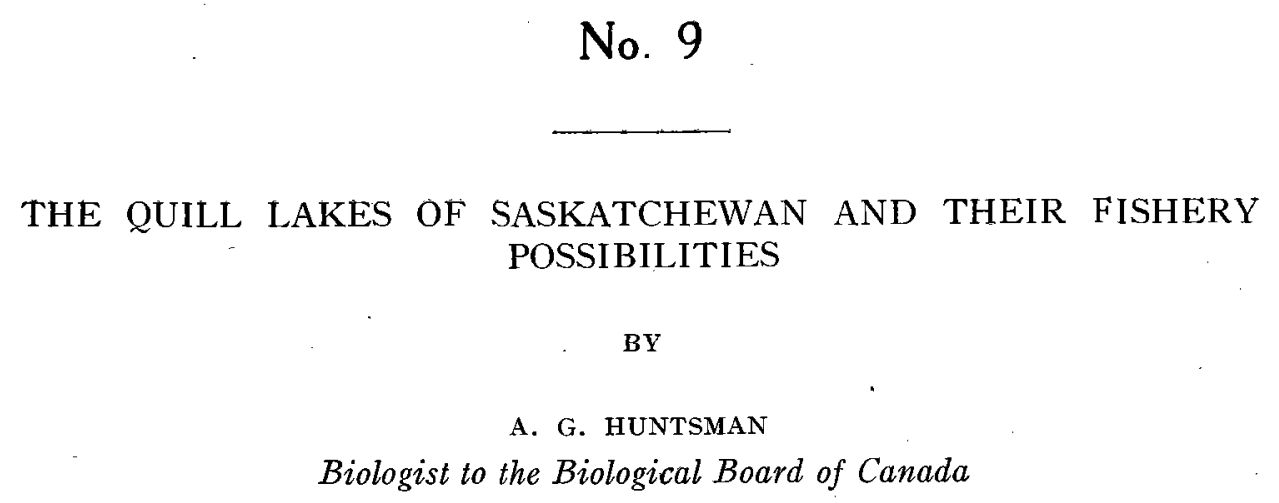




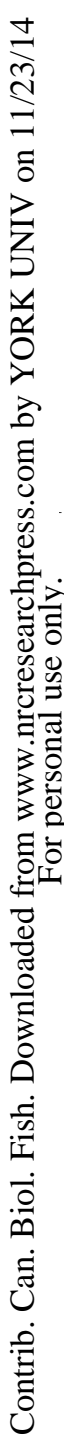




\title{
The Quill Lakes of Saskatchewan and their Fishery Possibilities
}

\author{
By A. G. Huntsman
}

\section{INTRODUCTION}

No part of our country is more poorly supplied with fish than is the prairie that makes up the settled portions of the provinces of Alberta and Saskatchewan, and also in part that of Manitoba. This prairie country is most distant from the sea coast, and at the same time it is poorly provided with large deep lakes. As a result of this situation there have been repeated requests for an improvement in the fish production of the lakes that exist in that region. The relatively small amount of moisture precipitated in many parts of this prairie country has not only caused a dearth of large bodies of water, but has also been responsible for the production of bodies of salt or alkaline water. This has occurred in places where the evaporation is much in excess of the precipitation, and where at the same time there are no deep channels to carry away the water rapidly. The various salts are leached from the soil by rains and carried into the lakes or ponds occupying the depressions in the land, and there they are concentrated by evaporation and more or less constant addition.

Among the most important of these saline lakes are the connected Quill lakes of central Saskatchewan. Requests, have repeatedly been made for their examination with a view to stocking them with fish. In the spring of 1920 an opportunity presented itself for me to visit these lakes in the course of a journey to Vancouver, B.C., and in this investigation I was so fortunate as to have the collaboration of Professor A. Willey of McGill University.

We were able to spend at the end of May two days at Little Quill lake and one at Big Quill lake. In our work we received great assistance from Mr. B. D. Branscombe of Wynyard, Mr. J. J. Stefansson of Little Quill lake, and Mr. J. G. Stephanson of Kandahar, to all of whom we are greatly indebted.

\section{EXTENT AND RELATION OF THE LAKES}

Together these bodies of water cover an area of over 230 square miles. The actual extent will vary to some degree with the level of the water in the lakes. From the maps furnished by the Department of the Interior the following have been calculated. Little Quill lake has an area of 70 square miles, with a length (nearly east and west) of 15 miles, and a breadth at the widest point of 6 miles. Big Quill lake has an area of 162 square miles, with a length (nearly north and south) of 18 miles and a breadth at the widest point of 11 miles. The area of the basin that is drained into these lakes is nearly 3,000 square miles. They have no outlet to the sea, and, therefore, the salts leached from the soil of the basin have been for a very long period drained into these lakes and concentrated there by evaporation of the water. If there has been at any time drainage out of the basin, it has doubtless passed from the south-western end of Big Quill lake through Saline creek into Last Mountain lake. Evidence in 
favour of this as the natural exit for the water is afforded in the first place by the levels in this region which decrease in the direction indicated, and in the second place by the presence of alkali-encrusted flats along this course, and by the name (Saline) given to the creek at the Last Mountain lake end of the course. These facts indicate that such drainage as has taken place along this course has consisted of saline water from the Quill lakes.

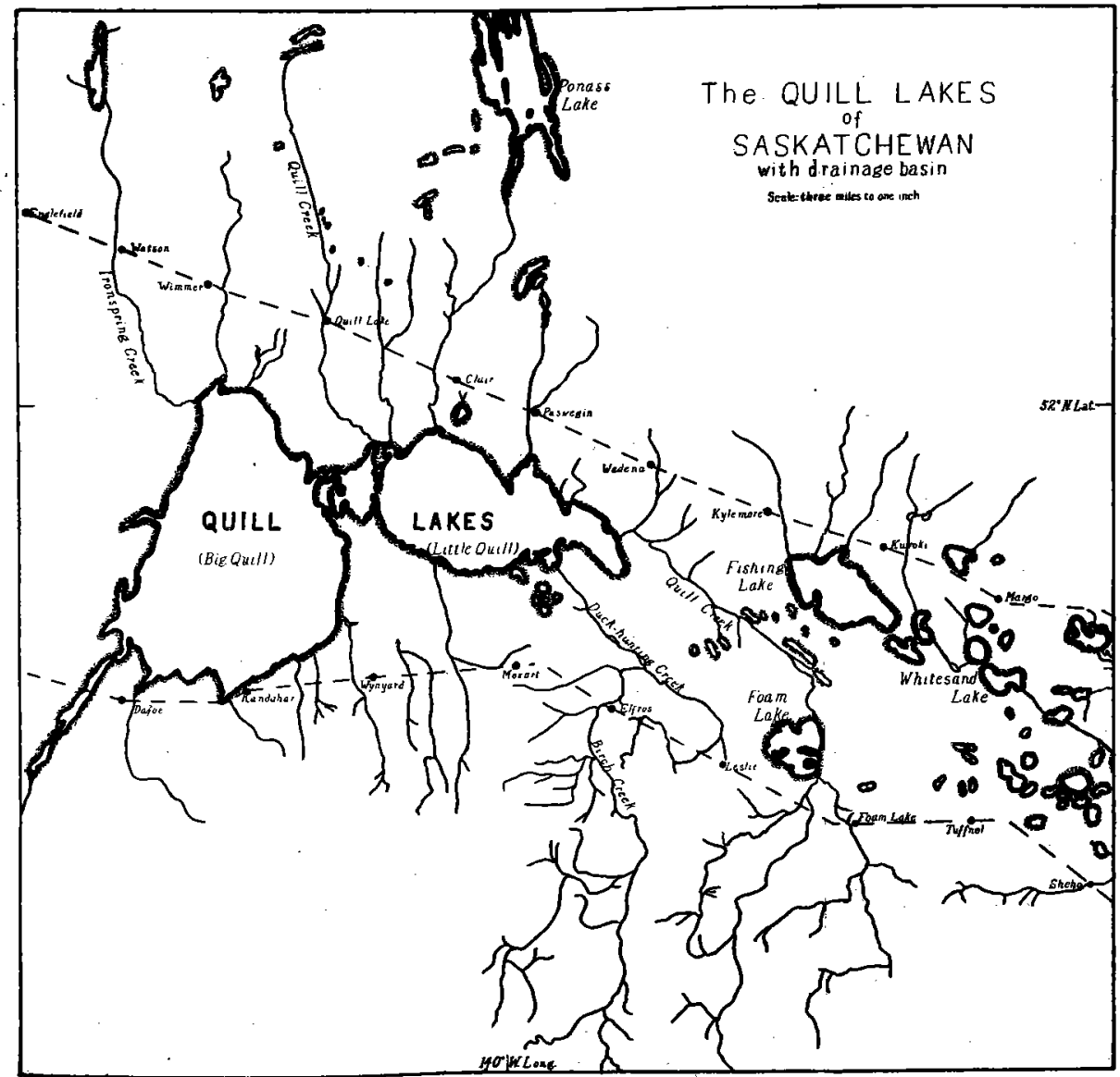

The two lakes are connected by a runway, an expansion of which, known as Mud lake, s so near the Little Quill as to be considered part of it. The three lakes form in fact one system with a common level. The drainage or chief movement of the water is from the Little Quill to the Big Quill, as will be seen from the following facts. The drainage basin of the Little Quill comprises some 1,900 square miles, while that of the Big Quill is scarcely 900 square miles in extent. The larger lake must, therefore, be supplied with a considerable portion of its water through the smaller one. This is corroborated by the finding of a greater percentage of salts in the larger lake. The runway permits of a certain amount of interchange of water in both directions when the wind acts upon the lakes, and thus prevents the development of any very great difference in salt content. 


\section{DEPTHS AND CHANGES OF LEVEL IN THE LAKES}

There was no opportunity for determining the maximum depths in the lakes. In harmony with the flat character of the surrounding land they are very shallow. According to Mr. J. J. Stefansson, who has fished all over it, the Little Quill is on the whole about ten feet deep, with perhaps fourteen feet as the greatest depth. Mr. J. G. Stephanson informed me that the Big Quill is about twenty feet deep with about forty (or perhaps even fifty) feet as the greatest depth. The shores of the Little Quill are low, and where examined consist of stones, gravel or sand, with very little mud or marsh. In the Big Quill on the northern side the land is very low, the shores in places marshy and the water shallow, while on the southern side the land is rather high, the shore for the most part sandy and stony, and the water deepening rapidly. The lack of outlet from the lakes is owing to the fact that on the whole the evaporation of water from the district is greater than the precipitation. For this reason the level of the lakes rarely, if ever, rises so high that the water can flow over the barriers between the Quill Lake basin and the neighbouring basins draining into the sea. As the level of these lakes is not controlled by an outlet, it will change from year to year and reflect the varying climatic conditions. According to Mr. Stefansson the level of the water in Little Quill a number of years ago rose about four feet and killed a poplar that was estimated to be about twenty years old. In recent years the level has gone down and is still lowering.

\section{TRIBUTARIES}

The streams or creeks which empty into these lakes are not very large, and are apt to run dry during the summer. By the action of storms the mouths of many of these creeks are blocked by bars of coarse sand or gravel through which the water filters.

The creeks that empty into Big Quill, and the areas of their drainage basins as calculated are as follows:

"Wimmer" creek. ..................... 122 sq. miles

Ironspring creek. . . . $\ldots \ldots \ldots \ldots \ldots \ldots \ldots \ldots \ldots \ldots \ldots$ "

"Dafoe" "

"Kandahar" creek....................... 38 " "

Unnamed $\ldots \ldots \ldots \ldots \ldots \ldots \ldots \ldots \ldots \ldots \ldots \ldots \ldots \ldots \ldots \ldots$ "

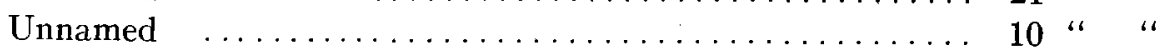

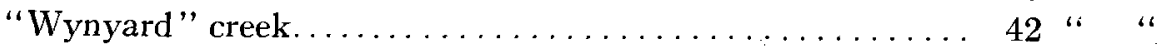

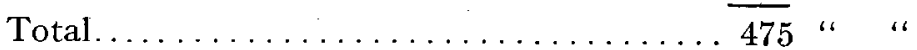
follows:

The creeks of the Little Quill with the areas of their drainage basins are as

"Mozart" creek. 125 sq. miles

Duck-hunting or Birch creek. . . . . . . . . . . . . 443

Quill (from Foam lake) creek. . . . . . . . .

"Paswegin" creek.........................130" "

"Clair" creek. . . . . . . . . . .

Quill (from Wetasta valley) creek. . . . . .

Total. . . . . . . . . . . 
From these figures it will be seen that the streams flowing into Big Quill must be insignificant compared with those of Little Quill. The two largest flowing into the latter, which are called Birch and Quill creeks, enter the small lake at its eastern end, the point farthest removed from the large lake. We were not able to investigate these larger streams. They empty into shallow bays protected from wave action by projecting points of land or islands, depending upon the level of the water.

In estimating the drainage area for Quill creek, which empties into the easternmost end of Little Quill lake, we have not included Fishing lake and its drainage basin. The latter lake is said to contain suckers, pike, and perch in abundance, and the appearance of these fish in the Quill lakes in recent years has been attributed to transference from Fishing lake. This lake is not shown with a definite outlet on the available maps of the region. From its position and the observed levels of the district it would seem as likely to drain into Quill creek as through Stony and Whitesand lakes eastward into Whitesand river, and the former drainage may have existed during the period of heavy precipitation when the level in the Quill lakes rose, as has been already mentioned.

\section{NATURE OF THE WATER}

Professor A. Vachon of Laval University, Quebec, undertook a chemical examination of samples of water from the two lakes, and has furnished the analyses which follow:

Results of analyses of water samples for radicles and salts, in grams per million cubic centimetres or parts per million.

\begin{tabular}{|c|c|c|c|}
\hline \multirow{2}{*}{ Radicles } & \multicolumn{2}{|c|}{ Little Quill Lake } & Big Quill Lake \\
\hline & Surface & 11 feet deep & Surface \\
\hline $\begin{array}{l}\mathrm{K}^{\prime} \\
\mathrm{CO}_{3}{ }^{\prime \prime} \\
\mathrm{Na}^{\prime} \\
\mathrm{Mg}^{\prime \prime} \\
\mathrm{SO}_{4}^{\prime \prime} \\
\mathrm{Ca}^{\prime \prime} \\
\mathrm{SiO}_{2} \\
\mathrm{Cl}^{\prime} \\
\text { Other salts and organic matter }\end{array}$ & $\begin{array}{r}120.47 \\
219.00 \\
1802.00 \\
825.77 \\
5676.00 \\
180.70 \\
7.40 \\
1197.50 \\
821.16\end{array}$ & $\begin{array}{c}\cdots \cdots \\
\cdots \cdots \\
\cdots \cdots \\
\cdots \\
\cdots \cdots \\
\cdots \\
\ldots \ldots \\
1216.00 \\
\ldots \ldots\end{array}$ & $\begin{array}{r}162.80 \\
235.80 \\
2537.00 \\
1169.08 \\
8368.00 \\
502.00 \\
10.40 \\
1937.00 \\
1627.92\end{array}$ \\
\hline $\begin{array}{l}\text { Total solids } \\
\text { Alkalinity }\end{array}$ & 10850.00 & 11110.00 & 16550.00 \\
\hline $\mathrm{OH}^{\prime}$ & 121.72 & 123.00 & 133.62 \\
\hline
\end{tabular}

These show the following: (1) A salt content nearly half that of the ocean, which is considered to be $31 / 2 \%$; (2) nearly $50 \%$ more salt in the big lake than in the little one; (3) a stratification of the water, the water at the surface containing less salt than that of a sample from a depth of 11 metres (36 feet); (4) a large amount of sulphate in the water (as opposed to a large amount of chloride in sea-water); (5) the relative amounts of the chief radicles (sodium, magnesium, 
sulphuric acid, chlorine, silica and potassium) practically the same in the two lakes; (6) significantly large differences in the relative amounts (per total salt) of calcium and carbonic acid in the two lakes, the smaller one having more carbonic acid and less calcium; and (7) the high degree of alkalinity of the water from both lakes (possibly rather different in the lakes themselves). Those living near the lakes have noted the scouring or purgative action of the water on cattle, which would be due to the large amount of sulphate present.

It is interesting to note that Devil's lake in North Dakota presents very similar conditions. Its history is known for a much longer period than is the case for the Quill lakes, and it has been repeatedly investigated. The total solids have varied much, having been as low as $0.85 \%$ in 1906 (Pope, 1908, p. 14) and as high as $1.9 \%$ about 1912 (Brannon, 1913, p. 30). This range includes what we have found to obtain in the Quill lakes. The total solids in Big Quill lake water about 1911 (Prince, 1912, p. 39) was apparently about $1.6 \%$, that is, almost exactly the same as in 1920 .

The percentage composition of the total solids is almost identical for the two Quill lakes, and for Devil's lake it is very similar, as appears in the following table:

\begin{tabular}{lc|c|c|c} 
& \multirow{2}{*}{ Little Quill Lake } & Big Quill Lake & \multicolumn{2}{|c}{ Devil's Lake } \\
\cline { 3 - 4 } & & & Pope, 1908 & Brannon, 1913 \\
\hline $\mathrm{K}$ & 1.10 & 0.98 & 2.11 & 4.02 \\
$\mathrm{Na}$ & 16.61 & 15.33 & 22.60 & 17.36 \\
$\mathrm{Mg}$ & 7.61 & 7.07 & 5.58 & 4.58 \\
$\mathrm{SO}$ & 52.30 & 50.60 & 52.7 & 53.10 \\
$\mathrm{Ca}$ & 1.66 & 3.06 & 0.21 & 1.26 \\
$\mathrm{SiO}_{2}$ & $\mathbf{0 . 0 7}$ & 0.06 & 0.24 & 0.15 \\
$\mathrm{Cl}$ & 11.20 & 11.71 & 9.68 & 9.50 \\
& & & & \\
\hline
\end{tabular}

The percentages have been calculated from the data given above for the Quill lakes and published by Pope and Brannon for Devil's lake.

The temperatures of the water in the lakes were as follows:

\section{LitTLE QUill LAKE.}

Near mouth of "Mozart" creek, at surface, May 28, 1920, 10 a.m., $15^{\circ} \mathrm{C}$.

East of mouth of "Mozart" creek and off shore in 11 feet of water, May 29, 1920. Surface, 12 noon, $10.4^{\circ} \mathrm{C}$.; 11 feet deep, 11.35 a.m., $10.5^{\circ} \mathrm{C}$.

\section{Big Quill LAKE.}

Opposite Kandahar, at surface, May $31,1920,7.00$ a.m., $7.4^{\circ} \mathrm{C}$.

We were informed that on May 14 Big Quill lake was still covered with ice. The ice disappeared first from the smaller lake, which accounts for the marked difference between the two lakes in temperature, which existed at the time of our visit. 


\section{Mollusca}

Rather large quantities of gastropod shells were found on the beaches of the two lakes, where in some places they formed an almost continuous coating over the sand or mud. Living Limnaea palustris were found in "Mozart" creek, but no living gastropods were found in either of the lakes. This may have been due to our examination of the lakes not having been thorough enough, but it is more probable that these forms are unable to live in the lakes, and that all that are carried there by the creeks during freshets die and leave their shells to be driven by the wind, and to be cast up on the beaches by the waves.

To Mr. Bryant Walker of Detroit, I am indebted for the identifications which follow:

Beach of Little Quill lake:

Succinea grosvenori Lea; Limnaea palustris Müller; L. caperata Say; L. vahlii Müller; L. vahlii arctica Lea; L. dalli Baker; Planorbis trivolvis Say; $P$. similaris Baker; Aplexa hypnorum L.; A. hypnorum tryoni Currier.

"Mozart" creek:

Limnaea palustris Müller (living); L. caperata Say.

Beach of Big Quill lake:

Limnaea obrussa decampi Streng.; L. palustris Müller.

\section{Crustacea.}

The largest form encountered was the Amphipod Hyalella knickerbockeri. This was very abundant in weed along the shores of both lakes. It should prove of considerable importance as fish food.

The group of small crustacea or entomostraca was represented by Copepods, Ostracods and Cladocera. Professor Willey, whoris reporting fully elsewhere on the material collected, has furnished the following account of those that were to be found in large quantities in a tow made with a No. 5 net near the surface in Little Quill lake on May 29.

Percentage of Entomostraca in the plankton.

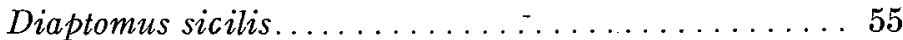

Cyclops parcus.................... 30

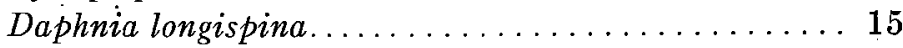

In addition there was a new species of the Harpacticoid genus Laophonte, proposed to be called Laophonte calamorum, scattered in important numbers through the gathering, but not enough to appear in the percentage count.

Daphnia pulex with summer eggs in the brood-pouch was present.

Ostracod valves, including that of Limnicythere reticulata Sharpe, were present.

Cyclops parcus showed frequent variations in the armature of the swimming feet.

The lake, therefore, supports a very abundant and somewhat varied entomostracan fauna in the open water, sufficient to provide a large amount of food for such fish as live upon plankton forms. 


\section{INSECTA.}

The only forms found swimming freely in the water so as to be taken in the plankton nets were Notonectids or water boatmen, belonging apparently to two species. Many of these were taken in Little Quill lake two to three feet below the surface in water from eight to eleven feet deep, with a coarse plankton net, and they were also found in Big Quill lake in abundance along the exposed beach at Kandahar.

The nymph of a damsel fly was found in small numbers in Little Quill and in large numbers in Big Quill lake, under stones and among vegetable debris in shallow water along the more precipitous beaches. Dr. E. M. Walker has examined these and informs me that they are probably the nymphs of Enallagma calverti Morse, but they may be those of E. clausum Morse, a related species which has not yet been reared from the nymph stage. The nymphs are mostly full grown, but some are in the penultimate and earlier stages.

As only a single haul was made with the dredge, very little knowledge was obtained concerning the forms on the bottom. Two Chironomids or midge larvae were taken in the haul (Little Quill lake) and others were found in the vegetable debris floating near shore in Big Quill. These larvae are doubtless very abundant on suitable bottom.

A few larvae of Caddis-flies were obtained and these were sent to Professor Cornelius Betten of Cornell University, who informs me that a species occurring in weed along the shore of Big Quill lake is Phryganea interrupta, and others from the shore of Little Quill and in "Mozart" creek are Limnophilids. No large numbers of these were seen.

\section{FISHES}

The most abundant fish in the lakes and tributary streams is the ninespined stickleback (Pygosteus pungitius), which is known locally as a minnow. It was found plentifully in "Mozart" creek and also along shore in both lakes in the masses of pondweed kept in motion by the waves. Twenty were taken in a 15-minute tow taken with a 30 in. plankton net, which would indicate that they are extraordinarily abundant. Five (that is one-quarter) of this lot were infested with large tapeworms in the coelome, and appeared swollen in consequence. Of those captured in the creek nearly one-quarter were affected in the same way. Quite a number of these sticklebacks were found dead cast up on the beach, and only part of these were infested with the tapeworm. These facts would indicate that they have not enough enemies in the form of large fish to dispose even of as many as are weakened by old age or disease. The stickle" backs seem to have been the only fish that were to be found in the lakes when the district was first settled. Mr. Stephanson, who lives near Kandahar, and who came to the district about 12 years ago, said the "minnows" were present in Big Quill from the time he first knew the lake.

The only abundant commercial fish in the lakes is the sucker (Catostomus commersonii). Mr. Stefansson, who came to the district in 1905, stated that at that time and subsequently the lakes were considered to have no fish and to be incapable of supporting them, although some of the older Indians living in the region related that formerly there were many fish in the lakes, but in recent 
years none. He, himself, believed that fish would be found in the lakes and tried systematically with nets to catch them. He first succeeded in 1908 in catching some suckers, from one to nine in a net all over the lake, and they were small. In 1909 they were more plentiful and they have become more numerous and larger since then, except that the last two years there has been no change. Some are obtained in the summer, but most are taken during the winter from the end of November on. The fishery is done through holes in the ice in the deepest water. Gill nets of from $3 \frac{1}{2}$ to $4 \frac{1}{2}$ inch mesh are used. Three men operating about 1000 yards of net may take up to nearly a ton of fish a day. They are used fresh, and also salted or even canned for local use. Considerable quantities are shipped in boxes to many neighbouring stations on the railway lines.

For the Big Quill lake Mr. Stephanson gave the information that there were no suckers to be found when he first came to the district. The first were got in 1910 and they were small. They have become larger and more abundant since. Suckers have been seen and caught running up the creeks of both lakes in the spring. The mouths of the two creeks, which we examined, were blocked with sand or gravel so that it was impossible for the suckers to have ascended as they were then. No evidence could be found of suckers having ascended these creeks to spawn. It is probable that only the larger streams, possibly only those at the eastern end of the smaller lake, are regularly open for the ascent and spawning of the suckers.

The abundance of the suckers was evidenced by the fact that the beach of Little Quill lake was strewn wherever we went with specimens that had been cast ashore. Professor Willey counted 300 in less than half a mile. Some were found on the beach of Big Quill, but they were said to have been much fewer than usual on the shore near Kandahar, owing to the wind having been in the wrong quarter after the breaking up of the ice. The explanation given of the abundance of these dead suckers was that they were the fish lost or discarded from the nets in stormy weather and washed ashore when the ice broke up. No net marks could be seen on any of the fish, so that it is more likely that they had died during the spring spawning season, not having been able to ascend the creeks. The striking thing in these lakes as compared with others is that both suckers and sticklebacks have not sufficient enemies to capture and devour the weakened and dying individuals. Nor are there sufficient animals such as crayfishes or other crustacea to dispose rapidly of the dead fishes.

Mr. J. J. Stefansson informed us that almost from the first appearance of suckers in Little Quill lake there has been a small proportion of "white" suckers, which are thin and deep, with large easily loosened scales, but with the typical sucker mouth. We have had no opportunity of examining and identifying - specimens of this fish.

Another fish that is now found regularly in these lakes is the pike (doubtless Esox lucius Linn.), of which, however, we were unable to examine any specimens. According to Mr. J. J. Stefansson, the first one was caught in Little Quill lake between 1910 and 1913, and a year passed before a second was seen. They have been rather steadily increasing in numbers, but even in 1920 they were not numerous. Their food consists of suckers. The pike occur also in Big Quill lake, but are much less abundant there. 
The only other fish reported as having been found in the lake was the perch, a single large specimen (nearly a foot long) of which was said to have been taken in Big Quill lake near Kandahar about the year 1918.

The evidence shows that there are very few species of fishes in the lakes; the only regular inhabitant being the small stickleback. Of the other four kinds that have appeared in recent years, three only are to be found generally. The origin of these fishes is uncertain, but it is probable that they came from the east through Quill creek, and possibly from Fishing lake, where they are said to be abundant.

\section{Diatoms}

Professor L. W. Bailey, of Fredericton, N.B., has examined and reported upon the species of diatoms occurring in our material from these lakes (Bailey, 1922). He has listed 63 kinds, of which 3 are considered to be new. Six species of these are usually regarded as wholly marine, that is, not occurring in fresh water. Certain species were extremely abundant in the tows taken with No. 20 bolting cloth plankton net, particularly in those from Little Quill lake. Miss C. W. Fritz of the University of Toronto has given me the following counts, showing the relative numbers of individuals of certain genera and species in two samples, one from each lake. The numbers are comparable only within each sample.

\begin{tabular}{l|r|r}
\hline \multicolumn{1}{c|}{ Diatom } & Big Quill Lake & Little Quill Lake \\
\hline Navicula & 10,776 & 288 \\
Amphiprora a & 144 & 9 \\
“ b & 128 & 333 \\
Pleurosigma a & 120 & $\ldots$ \\
“ b & $\ldots$ & 18 \\
Synedra b & 64 & 126 \\
Surirella striatula & 904 & 873 \\
“ ovalis & 56 & 243 \\
Campylodiscus & 8 & $\ldots$ \\
Nitzschia & 56 & 126 \\
Thalassiothrix & 448 & 48,690 \\
Chaetoceras & $\ldots$. & 11,394 \\
Melosira & $\ldots$. & 1.296 \\
\hline
\end{tabular}

The striking feature is the great predominance of the marine genera. Thalassiothrix and Chaetoceras. In fact with the exception of Navicula and Melosira (which contain both fresh-water and marine species), all the most abundant forms are exclusively marine. The amount of plankton obtained in Big Quill lake was very small compared with that from Little Quill. The differences between the two lakes in quantity and kinds of diatoms may be due in part to the season (as shown by the temperature) not being so far advanced in the larger lake.

\section{Other Algae.}

Professor A. B. Klugh of Queen's University has very kindly identified the Algae (exclusive of the diatoms), all from Little Quill lake. 
With No. 20 silk net at surface.

Enteromorpha prolifera tubulosa

Cladophora crispata

Nodularia spumigena

Pediastrum boryanum

scarce

common

abundant

abundant

On stones along shore:

Enteromorpha prolifera tubulosa)

Cladophora canalicularis

both abundant

" Mozart" creek:

Cladophora crispata

common

Oscillatoria formosa

scarce

O. tenuis

scarce

While the number of species is so small some of these are extremely abundant and furnish a very large amount of food for the animals of the lake.

\section{Higher plants.}

The only one of the higher plants occurring in the lakes is a pondweed which grows very abundantly at moderate depths as the fishermen testify. Large masses of this weed are rolled up by the waves on the beaches of both lakes. Professor R. B. Thomson of the University of To onto has diagnosed it (from slich fragments as were available at that time of the year) as Polamogeton pectinatus L., the fennel-leaved pondweed, widely distributed and occurring in fresh, brackish or salt water.

\section{COMPARISON WITH DEVIL'S LAKE, NORTH DAKOTA}

We have already shown how the physical and chemical conditions of the water in the Quill lakes greatly resemble those that obtain in Devil's lake, North Dakota. One would expect that the animals and plants found therein would be very similar, and to a certain extent this is the case, as will be seen from the following summary of the life of Devil's Lake.

Pike (called pickerel) formerly abounded in the lake, but disappeared when certain tributary bodies of fresh water were cut off by a series of dry years. In 1907 a minnow (Pimephales promelas) was abundant (Pope, 1908, p. 17), but seems to have disappeared since then. In 1917 the only remaining fish was the stickleback, Eucalia inconstans (Young, 1917, p. 506). Among insects backswimmers (Nòtonecta sp.) (Pope, p. 18) and midge larvae (Chironomus sp.) (Young, 1917, p. 506) are the most notable. The crustacea include an Amphipod (Pope, p. 18) (Hyalella?), the copepods Cyclops viridis and Diaptomus sicilis (Moberg, 1918, p. 246, etc.), and the Cladoceran Moina (Moberg, 1918, p. 243, etc.). There are a few extinct mollusks (Young, 1917, p. 506).

A single species of higher plant (Ruppia maritima) grows abundantly in the shallower water (Pope, p. 18, and Young, 1917, p. 506). Among the diatoms the genus Chaetoceras is prominent (Moberg), and of the other algae we may mention the genera Oscillatoria, Nodularia, Pediastrum, Enteromorpha and Cladophora, all abundant (Moore, 1917).

While there is general resemblance in the life of the two lakes or sets of lakes (in each case there is more or less subdivision of the water), a number of 
differences are manifest. Whether or not these are the result of such differences in the physical conditions as occur, we are of course unable to state, but it may well be that they are the result of more or less insignificant factors, and that forms occurring in only one of the two lakes could be successfully introduced into the other.

\section{DISCUSSION OF PROBLEM}

The problem under consideration is that of conserving and improving the fish production of the Quill lakes. The basis for fish production is plant growth. The minute floating plants such as diatoms and other algae are extremely abundant in Little Quill lake (and probably also in Big Quill lake at the proper season), and are in such variety as to be almost certain to ensure suitable food for the animals that live on these minute forms. Other algae grow in abundance on suitable shores and on the bottom. The single larger plant, the pondweed, though growing luxuriantly might well be supplemented by introducing the water-weed (Ruppia) that is so abundant in Devil's lake. Even without this the plant growth is sufficient to support a large population of fish.

Among the animals that serve as intermediaries in making the food from the plants available for the fishes, no group is more important than that of the Crustacea. Small species of this group occur in abundance and a somewhat larger form is to be found among the plants of the bottom. There is a lack, however, of large open-water forms and of large scavengers to make use of the dead fish. For the former need it might be advisable to introduce the shrimp Mysis relicta, that lives not only in fresh-water lakes, but also in brackish water along the sea coast. Crayfishes would be suitable as scavengers if they proved to be able to live in such saline waters, and an attempt should be made to introduce the species (Cambarus virilis) that lives in Last Mountain lake.

Of small fishes to serve as food for the larger ones there is only the stickleback. Its sharp spines make it rather unsuitable. It would be a distinct advantage to introduce the minnow (Pimephales) that formerly flourished in Devil's lake.

The larger fishes are of importance for direct use by man, and to keep up and increase their numbers is our final object. One resident of the district expressed the opinion that the suckers which are now abundant are all that is needed, and that the introduction of other species would not be an improvement. In support of this view is the fact that from the standpoint of the production of a large quantity of fish from the plants, that form the ultimate food source, suckers rate higher than such predatory fishes as bass, pike-perch, pike, perch and trout or salmon. The pike that now occur in these lakes are harmful and a nuisance in the view of those who are wanting suckers. If these latter fish are considered the most important what are the measures that should be adopted to maintain and increase the present supply?

The most important matter is to ensure that the suckers have access to suitable spawning grounds in the larger streams. Those emptying into the eastern end of Little Quill lake are probably the most constant and important, but all that offer proper spawning conditions, even if only in occasional years, 
should be brought into service. For each of these every spring before the time of the spawning run a passage should, if necessary, be cleared at the mouth so that the fish may be able to enter. In the fall a passage downward for the young should be assured. When these streams empty into sloughs or bays more or less perfectly barred off from the lake, it would be a very distinct advantage to retain the bar, or, if not too costly, even to build a permanent tight dam, with an opening just large enough to permit the fish to enter and the surplus water to escape. If there is not a constant flow of water out, the passage should be long and tortuous so as to prevent as far as possible the mixing of the water in the bay with that in the lake. Such bays, containing comparatively fresh water, would provide suitable spawning grounds for many fishes and also suitable feeding grounds for the fry and young until such time as they are able to endure the conditions in the lake. Similarly a dam and narrow passage at some point in the channel connecting the two lakes would keep the Little Quill in a better, that is, a less salt condition, such as makes it even now more productive than the larger lake. The flow, being from the small to the large lake, would, in the course of time, freshen the smaller lake, particularly if all possibility of a back-flow were prevented.

These measures that have been advocated for the improvement of conditions for the suckers are equally necessary for the majority of other fishes that it might conceivably be desirable to introduce. The fishes that live in water of varying salinity almost invariably spawn in fresh water, and fresh-water spawning grounds suitable for them must be available if there is to be a prospect of permanent success in their introduction into the Quill lakes. What fishes are most desirable and at the same time most likely to succeed in these waters? Opinions differ so much in regard to desirability that we can scarcely do more or less than to consider all those that find a market in our country at the present time. Two factors must be kept in view in selecting the kinds that are likely to succeed, and these are the food that is available and the salinity of the water.

What kinds of fish are likely to endure the salinity of the Quill lakes? We know that pike and suckers, and probably also perch, can do so. The United States Bureau of Fisheries and the North Dakota Biological Station have tested the resistance of a number of kinds of fish to the waters of Devil's lake by keeping them in tanks, the conditions admittedly not being ideal. Pike and suckers did not survive very long, but this may have been due not to the salinity, but to the confinement. Yellow perch, black bass, catfish, pike-perch, rainbow trout, and steel-head trout survived in good condition. It is remarkable that there was failure only for the two kinds that have succeeded naturally in the Quill lakes. Professor Prince (Report of Alberta and Saskatchewan Fishery Commission, p. 40) has suggested that the Atlantic brackish-water fishes, the tom-cod and the striped bass, might be successful, and a trial of these deserves to be made. Other species of fishes that have been found to occur in waters having a wide range in salinity are the following: eel, alewife or gaspereau, shad, smelt, whitefish, cisco (lake herring), white perch (Morone) and several trouts and salmons.

Eels could be planted with the practical certainty of their doing well. As they breed only in the open oceans there would be no danger of them becoming a permanent nuisance, if for any reason they were found to be undesirable. On 
the other hand, it would be necessary to restock regularly, at least every few years, and the young eels or elvers would have to be brought from the Atlantic coast It should be understood that this method of stocking inland bodies of water with elvers brought from the sea coast is regularly followed in many parts of Europe.

So far as our knowledge goes there is not at present much food of the right kind for yellow perch, black bass, pike-perch, steel-head trout, smelt, white perch, tom-cod, striped bass and salmon, although the introduction of large crustacea and small varieties of fish would doubtless remedy this condition.

The temperature reached by the water during the summer is probably so high as to be fatal to some of these fishes, but we have not yet sufficient information for a definite conclusion on this question.

There is plenty of suitable food for young fishes, and for the adults of such species as the alewife, whitefish and cisco. These fishes are very desirable from the standpoint of quantity production, and would almost certainly endure the salinity well. The only question is whether there would be suitable water for the spawning of the eggs and the rearing of the fry.

In any attempt to stock these lakes it should be arranged to plant the fish in the streams or bays at the eastern end of Little Quill lake. This would permit the fish to pass gradually into water of higher and higher salinity.

It is important to ensure protection of the fish from freezing during the winter. Both lakes are deep enough not to freeze to the bottom; but, if bays or sloughs are dammed off at the mouths of creeks a part of each should be made deep enough (for example, 8 to 12 feet) to provide a safe retreat for the fish that might remain in it over winter.

\section{SUMMARY}

The Quill lakes together form a connected body of saline water with an area of over 230 square miles and with depths ranging for the most part between 10 and 50 feet. As the evaporation is greater than the inflow from precipitation over the drainage area, there is rarely if ever, any outflow of water. The level of the water, consequently, has varied and will vary markedly from year to year depending upon the weather conditions. The drainage and the increase in salinity is from east to west as a result of the drainage area decreasing in the same direction, and of the natural outlet and the greatest depression for storing the water being at the west. The salinity of the water is from $1 \%$ to $1.65 \%$, and the chief salts present are Magnesium sulphate (Epsom salt), Sodium sulphate (Glauber's salt), and Sodium chloride (common salt).

There are many kinds of plants and animals in the lakes, but these are chiefly microscopic in size. The minute floating plants found in Little Quill lake were so abundant that a short tow with a fine-meshed net gave a bottle full of material of the consistency and appearance of pea-soup. Of larger plants there is a pond-weed growing in abundance at moderate depths and several simpler weeds coating the surfaces of boulders and other firm objects washed by the waves. Minute shrimps are found floating in the water in great abundance, as also a kind of insect known as a back-swimmer A shrimp of medium 
size and the larva of a damsel fly are common along shore. A small fish, known as a stickleback, is abundant almost everywhere. A sucker is the commonest large fish, but another sucker and the pike are said to occur regularly in smaller numbers. The lakes are tenanted by large numbers of aquatic birds, such as phalaropes, snipes, sand-pipers, terns, gulls, cormorants, ducks, geese and pelicans. These afford further evidence of the food-producing possibilities of these lakes.

There is every reason to believe that these waters could produce a much larger quantity and greater variety of fish than they do at the present time. To keep up and increase the fish production the most essential thing is to ensure fresh water conditions for the eggs and for the young fish, either in the streams or at their mouths, and at the same time to provide an avenue of access to these grounds for the adult fish at the proper season. If bays are dammed off for this purpose, part of each should be deep enough to serve as a retreat for the fish from the superficial layers that freeze during winter. Little Quill lake should be not only protected from an increase in salinity, but also given an opportunity to decrease in salinity, by the erection of a dam at a convenient point in the channel connecting the two lakes, a passage-way being kept open for fishes for a part of the year at least.

Attempts should be made to introduce other plants and animals to provide a greater variety of food for the fishes. If desired, other commercial fishes could be planted in the lake, and a number of kinds offer a good prospect of becoming permanently established providing suitable breeding grounds are available. Perhaps those most likely to succeed would be yellow perch, pike perch, alewife, smelt, whitefish and cisco. The eel would be very suitable for continuous planting.

We have not dealt with the use of artificial measures in keeping up the stock of fish in these lakes. Of the kinds of fish mentioned many could be hatched and some could be reared in much larger numbers by more or less artificial means than naturally, when the fresh water supply is limited. Such a course would, it is evident, not be advisable at the present time, but should be kept in view for the future. 


\section{LITERATURE}

BAILEY, L. W:

1922. Diatoms from the Quill lakes, Saskatchewan, and from Airdrie, Alberta. Contr. Canad. Biol. 1921, No. 11, pp. 155-166.

BRANNON, M. A.

1913. Second and third annual reports of the Biological Station to the Governor of North Dakota, pp. 1-36.

Moberg, E. J.

1918. Variation in the horizontal distribution of plankton in Devil's lake, North Dakota. Trans. Amer. Micr. Soc., Vol. XXXVII, pp. 239267.

Moore, G. T.

1917. Algological Notes. II. Preliminary list of algae in Devil's lake, North Dakota. Ann. Miss. Bot. Garden, Vol. IV, pp. 293-303.

Pope, T. E. B.

1908. Devil's lake, North Dakota. A study of physical and biological conditions, with a view to the acclimatization of fish. Bur. Fish. Doc. No. 634, pp. 1-22.

Prince, E. E.

1912. Dominion Alberta and Saskatchewan Fisheries Commission, 1910-11. Report and recommendations, pp. 1-71.

Young, R. T.

1917. The work of the North Dakota Biological Station at Devil's lake. Scient. Monthly, Vol. V, pp. 497-508. 